\title{
Semantic coindexation: evidence from Portuguese derivation and compounding
}

Alexandra Soares Rodrigues - IPB; CELGA- Universidade de Coimbra

Graça Rio-Torto - Departamento de Linguas, Literaturas e Culturas \& CELGA -

Universidade de Coimbra

This paper tries to shed light on the questions: How do words formed by word formation get their meaning? What are the factors involved and what is the balance between them?

According to Jackendoff's Parallel Architecture (2002), a word is an interface between Phonology, Syntax and Semantics, and formation of word meaning is independent of syntax. The PA permits us to solve some problems that come to light by adopting other perspectives (syntactically guided: Rappaport Hovav \& Levin 1992; Beard 1995; Lieber 2004; or cognitively guided: Barker 1998; Ryder 1999; Panther \& Thornburg 2002).

We propose to analyse Portuguese word formation of deverbal nouns and adjectives and of compounds, in order to test if these two genolexical mechanisms behave similarly respecting the semantic structure of their constituents.

Empirical data show that word formation mechanisms align semantic structuring independently of syntactic structuring. Only semantic features are responsible for the meaning of the coined word. This is shown by:

i) agent deverbal adjectives can be formed by verbal bases that in their argument structure lack an argument (Agent) corresponding to the meaning of the deverbal adjective. E.g.: chovedor 'that makes rain', suador 'that makes sweat'.

ii) event deverbal nouns, although sharing a verbal base and a general meaning 'event of $\mathrm{Vb}$ ', display different semantics according to the suffix. E.g.: $\left[[a n d a]^{\mathrm{V}} n c ̧ a\right]^{\mathrm{N}}$ 'adventure, journey', $\left[[a n d a]^{\mathrm{V}} \text { mento }\right]^{\mathrm{N}}$ 'speed or way of something going', [[anda $\left.]^{\mathrm{V}} d u r a\right]^{\mathrm{N}}$ 'physical way of moving'. The difference between their meanings comes from the coindexation of semantic features of the affix and semantic features of the base.

iii) concrete meanings (e.g. 'portion', 'residue', 'amounts') of some deverbal nouns (e.g. [[serra $\left.]^{\mathrm{V}} d u r a\right]^{\mathrm{N}}$ 'sawdust', $\left[[\text { ceva }]^{\mathrm{V}} d u r a\right]^{\mathrm{N}}$ 'rests of the bird that a bird of prey has been feed on'). These concrete meanings vary across affixes. Deverbal nouns constructed on the same base but with other affixes don't have the same concrete meanings $\left(\left[[\text { serra }]^{\mathrm{V}} c ̧ \tilde{a} o\right]^{\mathrm{N}}\right.$ 'the action of sawing', [[ceva $]^{\mathrm{V}}$ gem $]^{\mathrm{N}}$ 'the action of feeding' (causative construction)).

We propose that variation in the meanings across deverbal nouns is due to the semantic feature of each affix, besides other information domains - subsumed in Semantic structure - such as pragmatic-referential fields.

Semantic features that are the object of coindexation come from the lexical units involved, and also from other semantic structures.

Similar mechanisms of semantic coindexation are implied in $\mathrm{NN}$ (bébé-proveta 'test-tube baby', cão-polícia 'police dog', cimento-cola 'cement-glue', couve-flor 'cauliflower', pombo-correio 'carrier pigeon', retrato-robot 'Photofit picture') and NA (construção civil 'civil construction', estado civil 'marital status', guerra civil 'civil war', polícia civil 'civil police') compounds.

Despite their holistic meaning and their idiomaticity, these lexical constructions respect the major grammatical relations (conjunction, subordination, modification) underlying compounding. Their semantic structure reflects the 'maximal semantic 
frame' associated to each of the constituents, as well as the plausible semantic relations relying them. The distance between possible and lexicalized meanings they convey requires additional meaning computation, involving unexpressed features of the constituents (profile and/or proper functions of denotata, extralinguistic and cultural features), and coercion functions (Jackendoff 2009).

\section{References}

BARKER, Chris (1998) - "Episodic -ee in English: a thematic role constraint on new word formation". In: Language, vol. 74, n. ${ }^{\circ} 4$, pp. 695-727.

BEARD, Robert (1995) - Lexeme-morpheme base morphology: a general theory of inflection and word formation. New York, State University of New York Press.

BISETTO, A. \& Scalise, S. (2005) - The Classification of Compounds". I: «Lingue e Linguaggio» IV (2), 319-332.

FRADIN, Bernard (2005) - "On a semantically grounded difference between derivation and compounding". In Morphology and its Demarcations, Dressler W. U., D. Katovsky \& F. Rainer (eds) Amsterdam / Philadelphia: John Benjamins. http://www.llf.cnrs.fr/Gens/Fradin/FRA 3-double.pdf

JACKENDOFF, Ray (2002) - Foundations of language. Brain, meaning, grammar, evolution. Oxford, Oxford University Press.

JACKENDOFF, Ray (2009) - Compounding in the Parallel Architecture and Conceptual Semantics. In: Lieber \& Stekauer (eds), The Oxford Handbook of Compounding. Oxford, Oxford University Press, pp. 105-128.

JACKENDOFF, Ray (to appear) - Conceptual semantics. In: Semantics: an International Handbook of Natural Language Meaning. De Gruyter. http://ase.tufts.edu/cogstud/incbios/RayJackendoff/ConceptualSemantics.doc (accessed on 23/11/2009)

LIEBER, Rochelle (2004) - Morphology and lexical semantics. Cambridge, Cambridge University Press.

PANTHER, Klaus-Uwe \& THORNBURG, Linda (2002) - "The roles of metaphor and metonimy in English -er nominals". In: Dirven, René \& Pörings, Ralf (Eds.), Metaphor and metonymy in comparison and contrast. Berlin/ New York, Mouton de Gruyter, pp. 279-319.

RAPPAPORT HOVAV, Malka \& LEVIN, Beth (1992) - "-Er nominals: implications for the theory of argument structure". In: Stowell, Tim \& Wehrli, Eric (Eds.) (1992), Syntax and the lexicon. San Diego, Academic Press, pp. 127-153.

RODRIGUES, Alexandra Soares (2008) - Formação de substantivos deverbais sufixados em português. München: Lincom.

RYDER, Mary (2000) - "Complex -er nominals. Where grammaticalization and lexicalization meet?". In: Contini-Morava, Ellen \& Tobin, Yishai (Eds.) (2000), Between grammar and lexicon. Amsterdam/ Philadelphia, Benjamins, pp. 291-331.

ten Hacken, Pius (2000), "Derivation and Compounding", in Booij, Geert; Lehmann, Christian \& Mugdan, Joachim (eds.), Morphologie - Morphology : Ein Handbuch zur Flexion und Wortbildung - A Handbook on Inflection and WordFormation, Berlin: Walter de Gruyter, Vol. 1, p. 349-360. 